DOI: 10.32999/ksu2307-8030/2020-38-2

UDC 336.7:33.05-044.372

Korneliuk Olga
PhD in Economic Sciences, Senior Teacher of the
International Economic Relations and Project Management Department
Lesya Ukrainka Eastern European National University
ORCID: https://orcid.org/0000-0001-6620-1073

E-mail: ol-lu@ukr.net

Khirova Viktoria

Student of Master Specialty of

International Economic Relations and Project Management Department

Lesia Ukrainka Eastern Europen National University

ORCID: https://orcid.org/0000-0002-7379-8063

E-mail: vika.khirova98@gmail.com

\title{
FEATURES OF FORECASTING MODERN STOCK MARKET CRISES
}

In the scientific work, the essence of the concept of the stock market crisis is investigated and the premises and causes of the modern stock market crash of 2020 are analyzed. In particular, the theoretical foundations and practical aspects of the emergence and development of exchange crises are described in terms of their key characteristics. Also, stock indices, that form the market prices of securities and on the basis of which it is possible to monitor the volatility of the stock market, are analyzed. The dynamics of the largest falls of the Dow Jones stock exchange index is studied and a detailed description of the causes and consequences of each fall is presented. Based on the results of the analysis, the main prerequisites for the modern stock market crisis of 2020 are determined.

Keywords: stock market crisis, stock market crash, Dow Jones index, negative stock market dynamics, coronavirus.

КорнелюК О.А., Хірова В.Ю. ОСОБЛИВОСТІ ПРОГНОЗУВАННЯ СУЧАСНИХ БІРЖОВИХ КРИЗ

У науковій роботі досліджена теоретична та практична сутність поняття біржова криза та проаналізовані передумови і причини сучасного біржового краху 2020 року. Актуальність даної роботи підкреслює те, що функціональні структури, актори та суб'єкти діяльності ринку цінних паперів зазнали значних трансформацій і змін в останні роки. Одним із таких суб'єктів господарювання на сучасному етапі $€$ біржа, як організаційно-торговельний майданчик, на якому відбувається торгівля товарами або цінними паперами у вигляді стандартизованих біржових угод. Біржова торгівля виникла внаслідок удосконалення взаємин національного виробництва та міжнародної обміну, у результаті чого вона увібрала в себе риси як глобальної ринкової, так і локальної торгівлі. Основною метою бірж $є$ не прагнення одержати прибуток, а створити такі умови ведення торгівлі, які дадуть можливість одержати цей прибуток учасникам торгів, які в основному і є членами бірж. Саме через цю мету біржі вирізняються як особлива форма торгівлі. Проте такий формат торгів вирізняється й тим, що є дуже чутливим до внутрішніх та зовнішніх факторів впливу, які нерідко призводять до волатильності ринку та кризових ситуацій. Зважаючи на те, що біржові падіння та кризи сьогодні є надзвичайно багатогранним та складним поняттям, надзвичайно важливо дійти комплексного розуміння його сутності та механізму функціонування. Дослідження та аналіз явища дозволить вірогідно передбачати та запобігати їхньому виникненню у майбутньому, або мінімізовувати їхній негативний ефект. Зокрема, у даному науковому дослідженні було охарактеризовано теоретичні основи та практичні аспекти виникнення і розгортання біржових криз у розрізі їхніх ключових характеристик. Зокрема, детально проаналізовано біржові індекси, які формують ринкові ціни цінних паперів і на основі яких відстежують волатильність біржового ринку. Також у науковій статті досліджено динаміку найбільших падінь біржового індексу Доу-Джонса та подано детальну характеристику причини та наслідків кожного падіння. Виходячи з результатів проведеного аналізу, було визначено основні передумови сучасної біржової кризи 2020 року.

Ключові слова: біржова криза, падіння біржового ринку, індекс Доу-Джонса, негативна динаміка біржових торгів, коронавірус.

КорНеЛюК О.А., ХирОВа В.Ю. ОСОБЕННОСТИ ПРОГНОЗИРОВАНИЯ СОВРЕМЕННЫХ БИРЖЕВЫХ КРИЗИСОВ

В научной работе исследована сущность понятия биржевого кризиса и проанализированы предпосылки и причины современного биржевого краха 2020 года. В частности были охарактеризованы теоретические основы и практические аспекты возникновения и развертывания биржевых кризисов в разрезе их ключевых характеристик. В частности, детально проанализированы биржевые индексы, которые формируют рыночные цены ценных бумаг и на основе которых отслеживают волатильность биржевого рынка. Также в научной статье исследована динамика крупнейших падений биржевого индекса Доу-Джонса и представленя подробная характеристикя причин и последствий каждого падения. Исходя из результатов проведенного анализа, были определены основные предпосылки современного биржевого кризиса 2020 года.

Ключевые слова: биржевой кризис, падение биржевого рынка, индекс Доу-Джонса, негативная динамика биржевых торгов, коронавирус. 
Formulation of the problem. In recent years, the securities market has significantly complicated its structure because of the new approaches, tools and instruments. The speed of financial transactions and their volume also increased. At the current stage of development of the world market and global economy, the exchange is the most organized and developed form of trade, so it is impossible to overestimate the benefits of such a specific market environment. However, taking into the account the distinctive characteristics and key features of stock trading, the sensitivity to the fluctuations and instability of both world and national economies is immediately noticeable. Short-term and long-term stock market crises are a constant phenomenon of stock trading.

The analysis of researches and publications. The study of development and formation of stock market crises was carried out by such national and foreign researchers as Berysheva E. (the analysis of influence of information technologies on the stock market crises), Vasylik O. (the study of stock market crises as a part of the world theory of finance), Akworth W. (research about the state and prospects of the stock market crises), Zhdanova O. (the analysis of problems and prospects of stock market crises), Kovalenko M. (research about the functioning of stock market crises) and others.

The purpose of the work. In our research we wanted to analyze the essential of the exchange crises and to form the definition of this phenomenon. Also, concerning the current stage of economic development and global challenges which it meets, it is important to analyze modern processes on the stock exchange market to predict and prevent new exchange crisis. We researched prerequisites of the new stock market crisis in 2020 .

Presentation of the main research material. First of all, it should be noted that there is no generally accepted definition of the term "stock exchange crisis". Analyzing the interpretation of definitions by foreign and national scientists, we can conclude that the stock market crisis can mean a rapid and sudden decrease (which may last for months or years) of stock prices traded on the stock exchange, caused by the loss of investor confidence after a collapse, heightened by uncertainty. Usually this process is preceded by a period of prolonged and high inflation, economic and / or political turbulence, or chaotic speculative activity.

Such stock market crises disrupt normal economic activity, threaten millions of investors' savings and cause the deep economic decline of national economies in many countries.

Expanding the definition, it should be also noted that stock market crises are caused by the dynamics of social processes in the same way as the events of the traditional economy. Typically, a crisis signals about speculative bubble or catastrophic events of global significance. In any case, stock market participants start mass-selling securities, trying to liquidate assets such as stocks and bonds. Mass sales lead to an even higher rate of sale of securities as the market becomes crowded with assets and prices fall.

Other factors that cause the stock market crash include a long period of rising stock prices and excessive economic optimism. Economic downturns or even depressions can be caused by significant negative trends in the stock market [1].

Exchange crises require the central banks of the countries of the world to take extraordinary measures to restore the normal functioning of the market. Central banks tend to lower interest rates, stop trading or adjust market rules and provide liquidity to markets, including the financial sector. After the stock market crises, lawmakers are often forced to reform to address the underlying economic factors that have led to the fall.

In order to get a general picture of the state of the stock market, stock indexes are used, which form the market prices of securities and are calculated by one or another method of averaging the set of prices and revealing their overall dynamics.

The stock index is the average change in the value of a set of specific securities. It is worth noting that a similar indicator for a country's securities is called a nationwide securities market index. It has every state with a developed stock market.

To date, many different indicators (indices) of the securities market have been developed (table 1). All of them are regularly published and updated on the websites of brokers, exchanges, consulting companies, thematic information resources. The most well-known and oldest of these is the Dow-Jones Index, which tracks the change in the exchange rate of a number of US bond companies and stocks. Usually, each developed country has its own national stock market index. Thus, in the USA it is the Dow Jones Industrial Index, in England it is the Futsy Index (FT-SE), in Japan it is Nikki (NIKKEY), in Germany it is Dax (DAH), in France it is CAC (CAC) [2].

Tracking and analyzing the values of major stock indices of developed countries of the world allows us to identify stock market crises, explore the prerequisites for their emergence and prevent new stock market crashes. Thus, we analyzed the largest falls of the Dow Jones Industrial Index after 2008 (Figure 2) and identified the main causes of stock market crises that occurred at that time.

On May 6, 2010, leading US stock indexes, including the Dow Jones Industrial Average, the S\&P 500, and

Characteristics of individual indices of exchanges in different countries of the world

Table 1

\begin{tabular}{|l|l|}
\hline \multicolumn{1}{|c|}{ Stock index } & \multicolumn{1}{c}{ Characteristic } \\
\hline $\begin{array}{l}\text { Dow Jones } \\
\text { Industrial Index }\end{array}$ & $\begin{array}{l}\text { The Securities Exchange (Stock) Index of the 30 Largest US Enterprises, established in 1896. At the } \\
\text { basis of the Dow Jones Index is the theory of market analysis using average quotations of industrial } \\
\text { and transportation stocks. }\end{array}$ \\
\hline FTSE 100 & $\begin{array}{l}\text { The British Stock Exchange Index, based on the stock quotes of the 100 largest market companies on } \\
\text { the London Stock Exchange. It has been calculated since 1984. }\end{array}$ \\
\hline CAC 40 & $\begin{array}{l}\text { France's main stock index, which is based on the quotes of the 40 largest capitalized companies on the } \\
\text { Paris Stock Exchange. Established in 1987. }\end{array}$ \\
\hline Nikkei 225 & $\begin{array}{l}\text { One of the most important stock indices of Japan. The index is calculated as the arithmetic average of } \\
\text { the prices of the 225 largest companies in the first section of the Tokyo Stock Exchange. It was first } \\
\text { published in 1950. }\end{array}$ \\
\hline DAX & $\begin{array}{l}\text { The most important stock exchange index in Germany. The index is calculated as the weighted average } \\
\text { value of the stock prices of the largest German joint-stock companies. DAX was established in 1988. }\end{array}$ \\
\hline
\end{tabular}




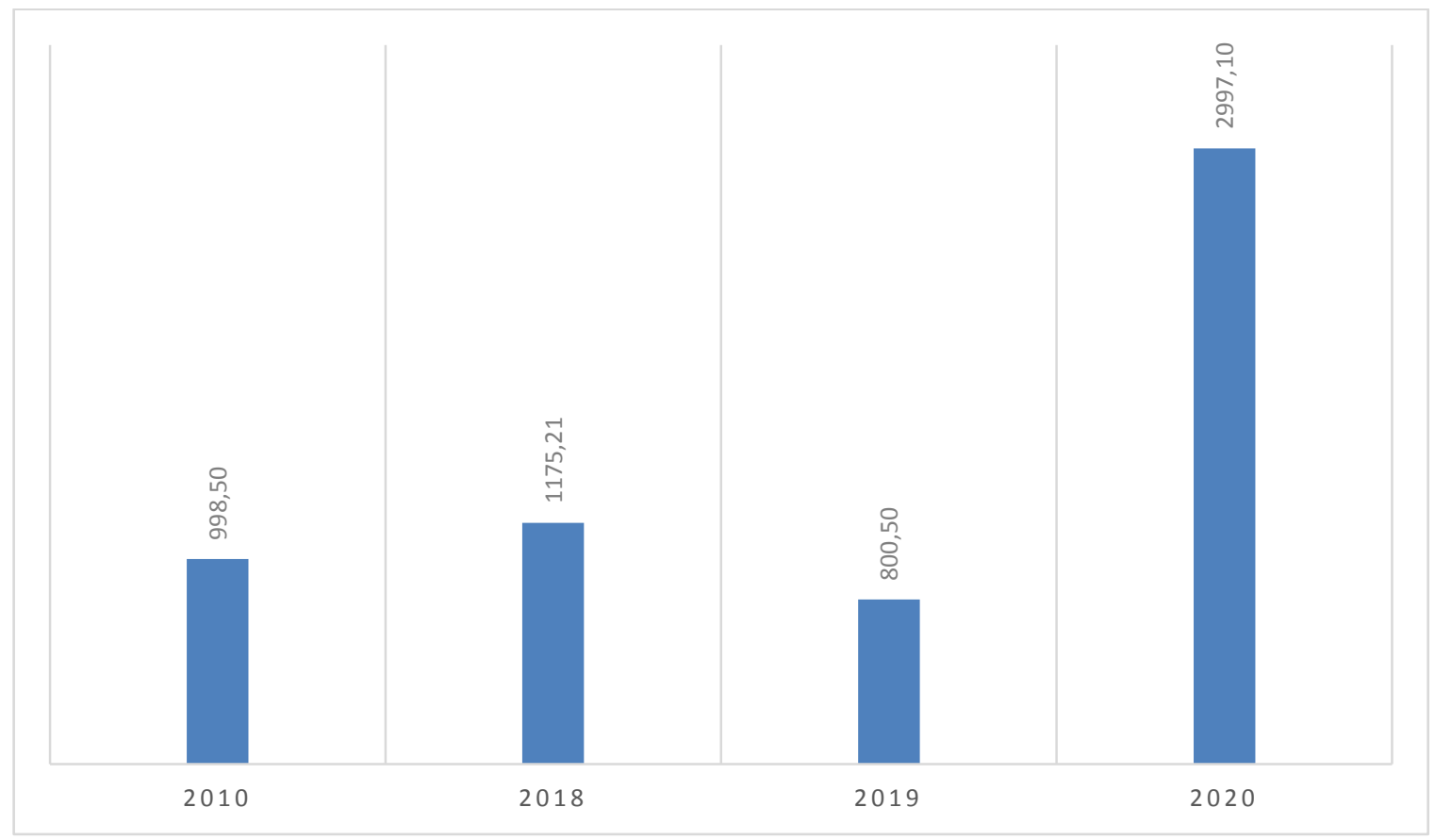

Figure 1. Dynamics of the largest falls of the Dow Jones Stock Exchange Index

Source: [3]

the Nasdaq Composite Index, fell nearly 1,000 points less than an hour on all types of securities, including stocks, futures and options. Although market indices managed to recover partially on the same day, the recession cost nearly $\$ 1$ trillion in market value [4].

Beginning in the morning, trading on the major US stock exchanges on May 6, 2010 showed a negative trend. This was mainly due to fears about the financial situation in Greece and the upcoming elections in the UK. In the afternoon, the main indices of stocks and futures decreased by $4 \%$. By $2: 30 \mathrm{pm}$, the auction had become extremely tumultuous. The Dow Jones
Industrial Index lost almost 1,000 points in 10 minutes (Figure 2) [4].

The results of various investigations have led to the conclusion that high-frequency traders (traders who use automated computer algorithms to enter into sales transactions that allow tens of thousands of transactions in a matter of seconds) have played a significant role in the fall. Aggressive sales and purchases of large volumes of securities have led to huge price volatility in the financial markets.

The fall of stock indices, and in particular the Dow Jones industrial index, in 2010 had a negative and

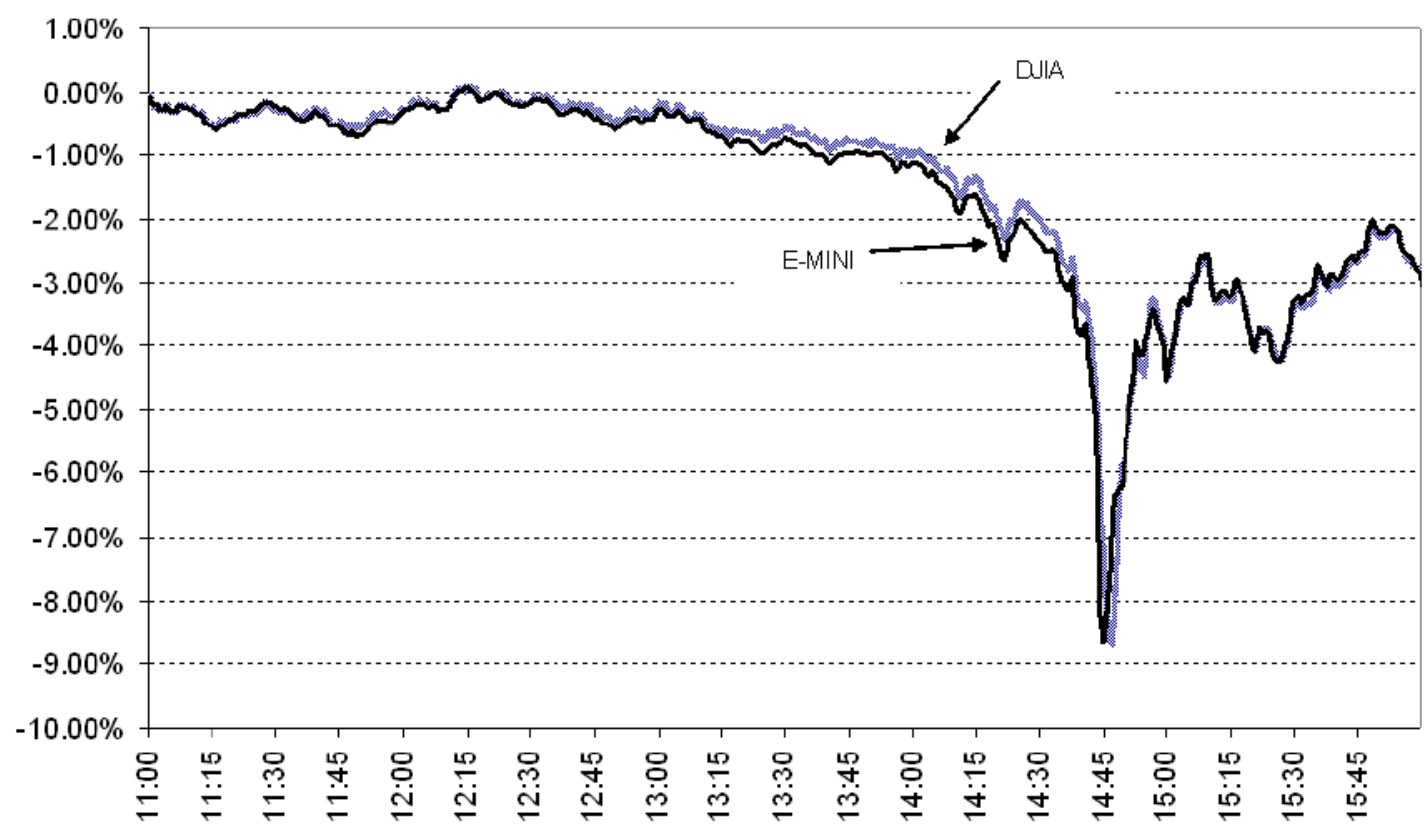




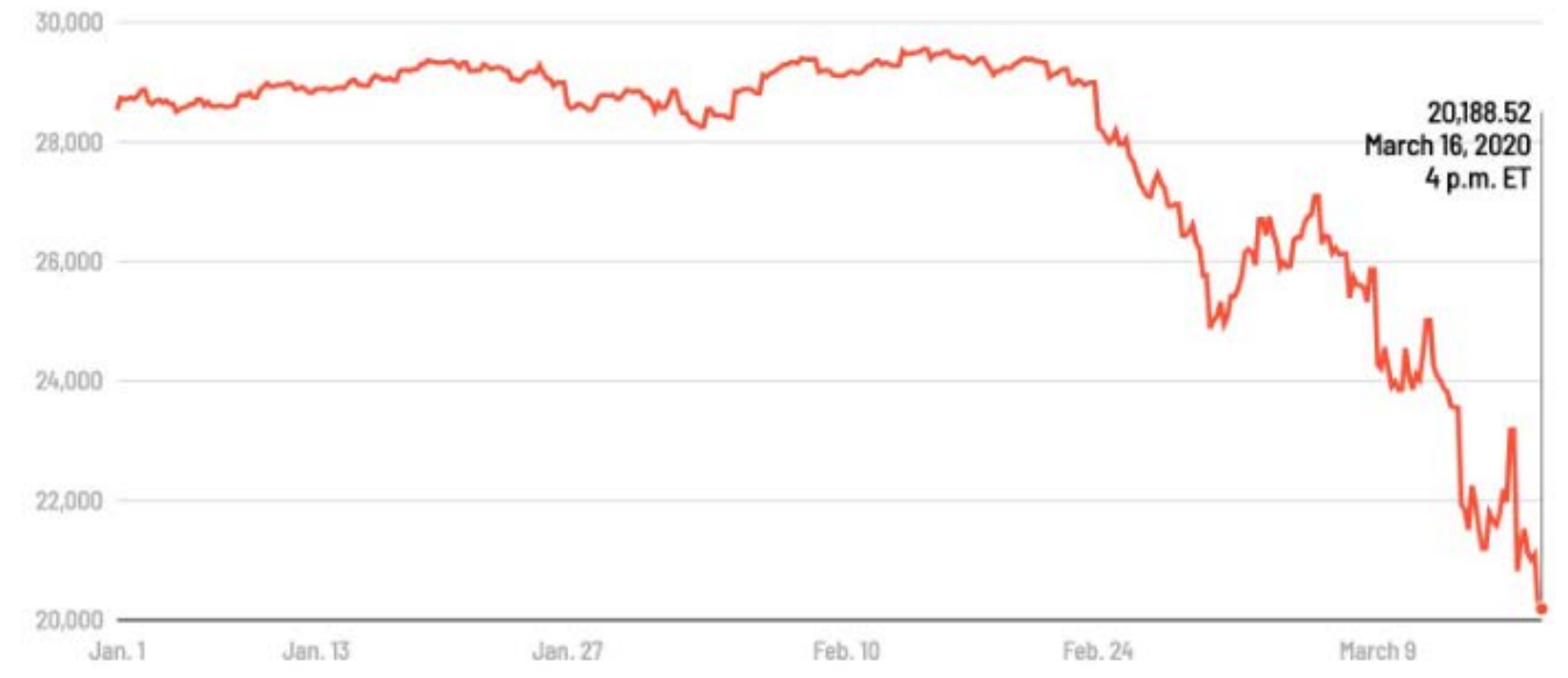

Figure 4. The negative dynamics of the Dow Jones exchange index because of the SARS-CoV-2 coronavirus

Source: [11]

Another evidence of the height of the new global stock market crisis was the fall in oil prices. On March 18,2020 , the price of the Brent brand fell a record by $13 \%$ to $\$ 24.88$ a barrel, it's the lowest level since May 2003. Such a sharp fall in oil prices was caused by the refusal of the Russian Federation to reduce production of "black gold". Saudi Arabia has responded to Russia's position with a collapse in prices: Saudi Aramco company has been ordered by the government to set discounts on crude oil. They reached $\$ 8$ per barrel and were the largest for the last 20 years [13].

Lower oil prices also led to a decline in global financial indices - with a decline of about five percent traded futures for US industrial indices, more than five percent collapsed Japanese Nikkei 225, Australian S \& P / ASX 200 - more than by 7\% [13].

Another global challenge become an international quarantine, which has been supported by most countries. Closure of borders, shutdown of large enterprises, closure of small and medium-sized businesses have caused an unprecedented turbulence when both investors and stock traders are unsure of their own assets and don't want to risk them. Panic in the stock markets was also fueled by the announcement of the IMF chairman about the beginning of a new world recession.

Thus, the situation with the new stock market crisis is only gaining momentum. Analysts predict a further fall in world indices and further volatility in the market, which will open the possibility of new speculative bubbles.

Conclusions. Therefore, it can be concluded that the stock market crisis is called a situation in which the stock market undergoes a sudden and significant fall in prices for its underlying shares. A stock market crash could be caused by a speculative bubble, a financial or an economic crisis. The negative effects of the stock market crash depend on both the major financial events that caused the problem and the pressure exerted on the stock market by investors who react to the negative news.

The global economy is currently in recession. International stock markets are experiencing a new crisis, which is compared with the fall of 2008-2009.

\section{REFERENCES:}

1. Personal finance company Bankrate. What is a stock market crash?. Available at: https://www.bankrate.com/glossary/s/stockmarket-crash/ (accessed 20th April 2020)

2. Financial markets. Fondovi indeksy: poniattia, kharakterystyka, vydy [Stock indices: concepts, characteristics, kinds]. Available at: http://buklib.net/books/26694/ (accessed 20th April 2020).

3. Sizzlers and Fizzlers Recourse. Research the all-time biggest gains and losses of The Dow and the S\&P 500. Available at: https://us.spindices.com/indexology/djia-and-sp-500/sizzlers-andfizzlers (accessed 20th April 2020).

4. M. Melin. What actually caused the 2010 «Flash Crash». Available at: https://www.businessinsider.com/what-actually-caused-2010flash-crash-2016-1 (accessed 20th April 2020).

5. Corporate Finance Institute. What is the 2010 Flash Crash? Available at: https://corporatefinanceinstitute.com/resources/knowledge/ trading-investing/2010-flash-crash/ (accessed 20th April 2020).

6. M. L. Schapiro. Testimony Concerning the Severe Market Disruption on May 6, 2010. Available at: https://www.sec.gov/news/ testimony/2010/ts051110mls.htm (accessed 20th April 2020).

7. The Two-Way Resource. Dow Plunges 1,175, The Biggest Point Drop In History. Available at: https://www.npr.org/sections/thetwoway/2018/02/05/583325123/stocks-extend-losses-with-dow-droppingmore-than-300-points-at-the-open (accessed 20th April 2020).

8. H. Kalachova. "Chornyi tyzhden» dlia finansovykh rynkiv: tymchasovyi strus chy pochatok novoi kryzy ["Black Week" for the financial markets: a temporary shakeup or the start of a new crisis]. Available at: https://www.epravda.com.ua/ publications/2018/02/9/633908/ (accessed 20th April 2020).

9. D. Shane. Global stocks swing wildly as investors worry about China's economy. Available at: https://edition.cnn.com/2019/01/02/business/ stock-markets-2019/index.html (accessed 20th April 2020).

10. E. Kurtenbach. Asian shares plunge after Wall Street's worst day since '87. Available at: https://apnews.com/f4dec5de0bc b4d32a1e28ada66e2fc6f?utm_campaign=SocialFlow\&utm medium=AP\&utm source=Twitter (accessed 20th April 2020).

11. M. Egan. Market volatility spikes to record high, taking out 2008 crisis peak. Available at: https://edition.cnn.com/business/live-news/stockmarket-news-today-031620/index.html (accessed 20th April 2020).

12. H. Demuryna. Torhy na birzhakh Kytaiu vidkrylysia obvalom na $8 \%$ cherez koronavirus [Trading on Chinese exchanges opened with a landslide of $8 \%$ because of the coronavirus]. Available at: https://www.rbc.ru/finances/03/02/2020/5e378b899a794758f22d3 c8e (accessed 20th April 2020).

13. L. Vannek. Rosiia i Saudivska Araviia obvalyly tsiny na naftu. Shcho vidbuvaietsia? [Russia and Saudi Arabia have slammed oil prices. What's going on?]. Available at: https://www.radiosvoboda.org/ a/30478035.html (accessed 20th April 2020). 


\section{БІБЛІОГРАФІЧНИЙ СПИСОК:}

1. Приватна фінансова компанія Bankrate. Що таке крах біржового ринку?. URL: https://www.bankrate.com/glossary/s/stock-marketcrash/ (дата звернення: 20.04.2020).

2. Фінансові ринки. Фондові індекси: поняття, характеристика види. URL: http://buklib.net/books/26694/ (дата звернення: 20.04.2020)

3. Ресурс Sizzlers and Fizzlers. Аналіз найбільших падінь та підйомів індексів Доу Джонса та S\&P 500. URL: https://us.spindices.com/indexology/djia-and-sp-500/sizzlers-and-fizzlers (дата звернення: 20.04.2020)

4. Мелін М. Що насправді спричинило «Flash Crash» у 2010 році. URL: https://www.businessinsider.com/what-actually-caused-2010flash-crash-2016-1 (дата звернення: 20.04.2020).

5. Корпоративний фрінансовий інститут. Що таке Flash Crash 2010 року? URL: https://corporatefinanceinstitute.com/resources/ knowledge/trading-investing/2010-flash-crash/ (дата звернення: 20.04.2020).

6. Шапіро М.Л. Свідчення щодо серйозних зривів ринку 6 травня 2010 року. URL: https://www.sec.gov/news/testimony/2010/ ts051110mls.htm (дата звернення: 20.04.2020).

7. Ресурс The Two-Way. Доу опускається на 1,175. Найбільший крах в історії. URL: https://www.npr.org/sections/thetwo-way/2018/02/05/583325123/stocks-extend-losses-with-dow- dropping-more-than-300-points-at-the-open (дата звернення: 20.04.2020)

8. Калачова Г. «Чорний тиждень» для фінансових ринків: тимчасовий струс чи початок нової кризи URL:https://www.epravda.com.ua/publications/2018/02/9/633908/ (дата звернення: 20.04.2020).

9. Шейн Д. Світові акції скажено коливаються, оскільки інвестори занепокоєнічерез економіку Китаю. URL: https://edition.cnn.com/ 2019/01/02/business/stock-markets-2019/index.html (дата звернення: 20.04.2020).

10. Куртенбах Е. Азійські акції знизились після найгіршого дня на Уолл-стріт 3 1987. URL: https://apnews.com/f4dec5de0bcb4d32a1e28ada66e2fc6f?utm_campaign=SocialFlow\&utm_medium=AP\&utm_source=Twitter (дата звернення: 20.04.2020).

11. Еган М. Нестабільність ринку зросла до рекордного рівня, досягнувши піку кризи 2008 року. URL: https://edition.cnn.com/ business/live-news/stock-market-news-today-031620/index.html (дата звернення: 20.04.2020).

12. Демурина $X$. Торги на біржах Китаю відкрилися обвалом на $8 \%$ через коронавірус. URL: https://www.rbc.ru/finances/ 03/02/2020/5e378b899a794758f22d3c8e (дата звернення: 20.04.2020).

13. Ваннек Л. Росія та Саудівська Аравія обвалили ціни на нафту. Що відбувається? URL: https://www.radiosvoboda.org/ a/30478035.html (дата звернення: 20.04.2020).

Стаття надійшла до редакиї 02.05.2020.

The article was received 02 May 2020 